\title{
Puchon 2000
}

\author{
By Toh, Hai Leong \\ Spring 2001 Issue of KINEMA
}

\section{THE 4th PUCHON INTERNATIONAL FANTASTIC FILM FESTIVAL 2000}

Only in its fourth year of operation, the Puchon International Fantastic Film Festival (PiFan) has become an important and unique festival in Korea. Despite being a year younger than its well-regarded counterpart, the Pusan International Film Festival, PiFan has already earned a reputation as a role model for festivals concentrating on the theme of fantasy. Just this year, it launched the Made In Korea section, ahead of Pusan, introducing films by an emerging wave of local talent such as the highly elegiac Kim Ki-duk. Two of Kim's new films, The Isle (Seom, 2000) and Real Fiction (Siljaesanghwang, 2000) were shown at the festival, helping to solidify its position as a venue for showing world standard works of art and entertainment.

The festival has also launched the Asian premieres of independent American and European films which has gone on to create waves and to "shock" other politically correct film festivals -- a few examples would suffice: Les Bernstein's film noirish debut, Night Train (USA, 1999), Brian O'Hara's underground necrophiliac Rock "N" Roll Frankenstein (USA, 1999), Richard Wolstencroft's intellectual, sado-masochistic Pearls Before Swine (Australia, 1999) and the searing sex documentary, Dag Yngvesson's Rated X -- A Journey Through Porn (USA, 1999).

As with all good festivals, PiFan is not only a launching pad for new filmmakers but also a place where those involved in film can interact, collaborate and engage in a free exchange of ideas. In the Official Competition section, an international jury for fiction features awards the Golden Kebbi (the Korean term for an unborn infant) in 5 categories: Best Film, Best Director, Best Actor, Best Actress, Best Audience while a national jury for short films gives out the Golden Kebbi in 3 categories: The Grand Prize worth US $\$ 5000$, the Jury's Award and Audience Award. In all, 50 shorts from 20 nations were chosen judiciously, with the youthful Korean short filmmakers making the most impact. Among them, Kim Han Min's Sunflower Blues, Suh Myung Soo's Morning 83 Morning stood out with their quirky psychological stories, shot on $35 \mathrm{~mm}$

The World Fantastic Cinema section features the best in horror, thriller, science fiction and fantasy cinema (25 films). Not surprisingly, the Japanese horror films -- Ring O, Ring 1 and Ring 2 -- The Sequel, and Mike Mendes' demon film, The Convent drew the most spine-chilling screams from hysterical young fans. Independent films, 28 in all, that have somehow defied the stranglehold of Hollywood, were included in the Cinemasphere section, with Singapore's own homegrown feature Forever Fever, re-titled That's the Way I Like It (DVD version) making a humble representation. Five family films were included in the programme with the added element of fantasy. Three of these, Digging To China, Babel and Sherdil were screened to huge audiences in the open theatre just outside the Puchon City Hall. Finland, the Land of the Midnight Sun, took the limelight this year with 9 features on the theme of "Love and Anarchy", made between 1998 and 2000 plus an additional 4 short films.

Tribute was paid to the late prolific actor Choi Moo-Ryong, a '60s national screen hero and icon in Part 1 of the Made in Korea section. Four of his films were shown in a collection titled "Homage to the Artist, the Man, the late Choi Moo-Ryong". PiFan's conscientious effort to promote contemporary Korean films is titled simply Showcase featuring 5 major current releases plus one noteworthy documentary Shoot The Sun By Lyric (Noraero Taeyangeul Ssoda,1999) on the fight to preserve the 108-day screen quota system to counter the onslaught of Hollywood movies, and 12 shorts. One of the most popular events was the section called Sleepless in Puchon: Midnite Screenings in which 4 films of various genres were shown from midnight till dawn to energetic, enthusiastic, youthful audiences who jam-packed the auditorium at the Boksagol Cultural Centre.

Recently, a number of credible festivals have included in their programmes incisive sex documentaries which dare to challenge audiences' politically correct perceptions. For example, both the Sundance Film Festival and The Hong Kong International Film Festival have screened Gough Lewis's 3-year inquest into the exploits of Singapore's infamous Annabel Chong (aka Grace Quek) in which she had impersonal sex with 251 men 
in 10 hours, in a documentary called Sex: The Annabel Chong Story (USA, 1999). The Hong Kong festival also showed Christine Fugate's innocently-titled The Girl Next Door (USA, 1999) about the well-endowed Stacy Valentine and her survival strategy in the highly exploitative and competitive hard-porn film industry. The pornography business in the United States, centered in Los Angeles' notorious San Fernando Valley, rents about 500 million videos yearly and generates an annual revenue of more than US $\$ 8$ billion. It has also attracted major companies from all over the world.

The $4^{\text {th }}$ PiFan presents the anthropology-trained, porno-film connoisseur Dag Yngvesson who, after five and a half years of self-financing, has made a documentary Rated $X$-- A Journey Through Porn about the men and women involved in the world of hard pornography. The film begins with the director's self-confession and wry comments as he discloses revelations of his early teen encounters with tacky porn space aliens from films like Carnal Encounter of the Barest Kinds and other B-grade movies. Newcomers to the industry such as Selena, Kirsty Waay, Michael J. Cox and veterans like John Leslie, an actor-turned-director, Jeanna Fine, Sean Michaels (a Black actor-cum-producer), Mark Davis, Steve St. Croix, Dick Nasty and even woman filmmaker Toni English, provide insight into Hollywood's Babylonian twin.

What surfaces is that most of the women participants or workers in the sex film industry have been neglected and abused sexually in their childhood or youth, often and used by their boyfriends. The director highlights the case of porn superstar Jeanna Fine who tells her tale of woe and exploitation -- emotional abuses, zilch guidance from negligent parents and her descent into hell -- from drugs dependency, homelessness, to emotional and sexual domination by an abusive ex-boyfriend. Now rehabilitated and a mother as well, she is apparently back in the business to support her husband and child.

Candid as ever, Yngvesson even accepted the assignment of cameraman on the set of a hard core film. At the end of the screening of his documentary, however, the filmmaker told the audience, "I am pushing on. No more porn for me!" The central concern of his documentary was the "high risk factor that came with the job"-- Aids, venereal warts and other sexual transmitted diseases that came with the promiscuous sexual intercourse on the set. Though the film acknowledged the lack of black representation, the racial issue was treated in a somewhat cursory manner and the existence of American-Asians in the porn industry was virtually ignored.

On a lesser note, Hong Kong's The Mistress, directed with panache by former disc jockey Crystal Kwok is a lushly photographed, finely observed film about an emotionally immature woman who falls for a philandering businessman (played by Ray Lui Leung-wai). It probably contains the first ever woman's fantasy scenes of eroticised sex, very much like a scaled down version of Buñuel's Discreet Charm of the Bourgeoisie. Kwok's subtle and effective criticism of the rich man's power over the lives of his women is shown in the boredom of the tai tais, ladies of leisure who play the love game with their unfaithful husbands and toy boys, and evident in the emotional isolation of the kept mistresses.

\section{Author Information}

TOH Hai Leong is a Singapore-based freelance film critic and filmmaker (Zombie Dogs, 2005) who writes for independent film publications such as Screen International and World Paper. He has covered the Hong Kong International Film Festival since 1985 and specializes in the cinemas of Hong Kong, Taiwan, China, Korea and Japan. 